\title{
The Current Status of Begomovirus Research in India: Solemn Threat to Crop Production
}

\author{
Manju Sharma*, Priya Singh, A.K. Tewari and Pranesh Lavania \\ Department of Plant Pathology, GB Pant University of Agriculture and Technology, \\ Pantnagar, Uttarakhand, India \\ *Corresponding author
}

\section{A B S T R A C T}

Keywords

Begomovirus, Solemn threat, Crop production

Article Info

Accepted:

04 August 2018

Available Online:

10 September 2018
Begomoviruses being the largest genera of Geminiviridae cause significant economical losses in a wide variety of crops in several tropical and subtropical regions of India and a major threats to food security. Begomoviruses are transmitted by the whitefly (Bemisia tabaci) in a circulative persistent manner. Begomoviruses as of their small genomes (ssDNA) and limited coding capacities, rely heavily on host machineries for infection. They interact with a wide range of plant proteins and process them to support viral DNA replication, gene expression, movement, and to neutralize host defenses. Many of these interactions have antagonistic effect on the growth of crops, resulting in symptoms that include stunting, vein clearing, curling, leaf deformation and loss in fruit quality and production. The main research studies focused on Begomoviruses are: identification, molecular characterization, sequence analysis, DNA replication, infectivity, phylogeny, functions of viral proteins, virus-host interaction, transgenic resistance, promoter analysis and virus based gene silencing vectors. This review presents current status of begomovirus research in India and future areas that need to be explored.

\section{Introduction}

Begomoviruses are emergent pathogen widely distributed in tropical, subtropical and temperate regions worldwide and are a serious threat to diverse economically important crops (Castillo et al., 2011; Varma et al., 2011). The genus begomovirus is the largest among seven genera viz. Becurtovirus, Begomovirus, Curtovirus, Eragrovirus, Mastrevirus, Topocuvirus and Turncurtovirus classified in family Geminiviridae (Brown et al., 2015; Varsani et al., 2014). Begomoviruses are small ssDNA viruses transmitted in a circulative persistent manner by the whitefly (Czosnek, 2007).

Begomoviruses have either a monopartite (single DNA) or a bipartite (two DNA components: DNA-A and DNA-B) genome organization, infecting mostly dicotyledonous plants. The DNA-A of bipartite and the single component of monopartite begomoviruses contain five (sometimes six) Open Reading Frames (ORFs), one (AV1) or two (AV1 and $\mathrm{AV} 2)$ in the viral sense (V-sense) strand and four (AC1 to AC4) in the complementary sense (C-sense) strand. Both the DNA-A and 
DNA-B are approximately $2.8 \mathrm{~kb}$ in size. The DNA-B contains two ORFs (BV1 and BC1, in $\mathrm{V}$-sense and $\mathrm{C}$-sense strand, respectively). In DNA-A, AV1 codes for coat protein (CP), the AV2 for a protein of unclear function, $\mathrm{AC} 1$ for a replication associated protein (Rep) and AC2 for a transcriptional activator (TrAP).The protein encoded by AC3 is the replication enhancer (Ren) and the protein encoded by AC4 functions as a suppressor of RNA silencing. In DNA-B, the BV1 codes for a nuclear shuttle protein (NSP) and the BC1 for a movement protein (MP), required for intracellular and intercellular movement of the viral DNA respectively. The non-coding region (called Intergenic region-IR, approximately $500 \mathrm{bp}$ ) contains the origin of replication, where the viral Rep protein binds for initiating rolling circle replication. A part of this region is conserved between the two DNA components of bipartite begomoviruses. The IR also harbours the promoter/ regulatory elements for expression of the viral genes in both $\mathrm{V}$-sense and $\mathrm{C}$-sense strand.

Monopartite begomoviruses are often associated with satellite DNAs, about $1.4 \mathrm{~kb}$ in size. Two types of satellite DNAs are known: the alpha satellites and beta satellites. The alpha satellites encode their own replication-associated protein whereas, the beta satellites do not code for any replication associated proteins but carry a single ORF $(\beta C 1)$, encoding a multifunctional protein. Both the alpha and beta satellites are dependent upon the helper virus for replication and, in many cases, attenuate the symptoms produced by it (Idris et al., 2011).

All begomoviruses encode a coat protein (CP) in which all the genomic and satellite molecules are present. The CP acts as the coat of the virus particles and is essential for virus transmission from diseased to healthy plants by $B$. tabaci. The $\mathrm{CP}$ is therefore an essential component of begomovirus survival and has been used widely to characterize and establish the relationships of many begomoviruses (Harrison et al., 2002).

Plants use a combination of transcriptional gene silencing and post transcriptional gene silencing as defense against begmovirus infection. Viral infections in plants trigger the defense responses by degradation of the invading viral RNA into small fragments (siRNA), phenomenon known as RNAinterference (RNAi). Therefore successful viral infection results only upon suppression of this defense response by specific viral proteins, known as RNAi suppressors. RNAi suppressor activities have been discovered in several begomoviral gene products (Voinnet, 2005).

Genetic resistance against plant viruses, if available in the germplasm, is considered to be one of the most efficient ways to control viral infections for example it is appraised during research studies that out of 26 collections of pumpkin, seven namely, LC-1, LC-2, LC-3, LC-4, LC-5, LC-6 and LC-9 were highly resistant to viruses (Sharma et al., 2012, 2013). The genes conferring such resistance can be transferred to cultivated varieties by breeding. Against begomoviruses, very few resistance genes are known, the most important of them being the Ty series of genes available in wild tomato (Solanum chilense) against Tomato yellow leaf curl virus (TYLCV). Transgenic resistance against begomoviruses has been achieved in a number of plants using a variety of strategies.

The strategies which includes expressing proteins of viral origin (CP, Rep and its derivatives and TrAP), expressing nonviral proteins having an anti-viral effect (toxic protein dianthin, antibodies raised against viral $\mathrm{CP}$ ), DNA interference involving defective viral DNAs and RNAi against viral transcripts (Vanderschuren et al., 2007). 
Earlier emerging threat of begomoviruses on crop yield has been extensively addressed (Varma and Malathi, 2003). The extent of yield loss caused by some begmoviruses has been estimated to be as high as 100 per cent (Dasgupta et al., 2003; Borah and Dasgupta, 2012). Bhendi yellow vein mosaic virus reported to cause up to 96 per cent loss in yield (Pun and Doraiswamy, 1999). Yield losses in blackgram, mungbean and soybean have been estimated to be approximately $\$ 300$ million per year (Varma and Malathi, 2003).

Presently in India a large number of begomoviruses have been identified which infecting the various crops. Researchers in India are recently focusing on the molecular interactions between begomoviruses and their hosts with the objective to gain insight on the molecular cross-talk, which might throw light on newer and hitherto unexplored aspects of their biology and reveal novel approaches for their management.

Considering the importance of begomoviruses in India, the salient research achievements related to begomoviruses, have been reviewed here. The review describes our current knowledge of how begomoviruses interact with their plant hosts, functional consequences of these interactions and the possible directions in which future efforts could be channeled to manage diseases caused by begomoviruses.

\section{Begomovirus research in India}

Begomoviruses have been reported from different groups of crops in India. Extensive research work has been done on these viruses such as sequence analysis, phylogeny, infectivity, virus host interaction, functions of viral proteins; virus derived transgenic resistance and associated satellites. The review brings together the research work performed in India, focusing on the above aspects, described in the alphabetical order of their major hosts below.

\section{Bhindi}

Bhendi yellow vein mosaic disease was first reported from Mumbai in India by Kulkarni. In India, distinctive monopartite begomoviruses such as Bhendi yellow vein Madurai virus (BYVMV), Bhendi yellow vein Bhubaneswar virus (BYVBhV), Bhendi yellow vein Maharashtra virus (BYVMaV) and Okra enation leaf curl virus (OELCuV) have been reported (Fauquet et al., 2008; Brown et al., 2012; Venkataravanappa et al., 2012b, 2013a,b). Besides these, Bhendi yellow vein Delhi virus (BYVDV), a new bipartite begomovirus species, was recently found to be associated with YVMD on okra (Venkataravanappa et al., 2012a). Inoculation of bhindi plants with cloned BYVMV DNA, a monopartite begomovirus, produced mild symptoms; typical vein yellowing symptoms were produced only in association with the cognate beta satellite (Jose and Usha, 2003), possibly due to the silencing suppression activity of the $\beta \mathrm{C} 1$, reported later (Gopal et al., 2007). The CP showed nuclear localization, whereas the $\beta \mathrm{C} 1$ localized to the cell periphery (Kumar et al., 2006).

\section{Brinjal}

Brinjal is also found to be infected with a variant of the Tomato leaf curl New Delhi virus (Tolcvnd). The researchers identified cloned and sequenced the complete DNA-A and DNA-B genomic components of the causative virus (Pratap et al., 2011).

\section{Cassava}

Cassava mosaic disease (CMD) had been reported in India in 1966. Indian cassava mosaic virus (ICMV) and Sri Lankan cassava 
mosaic virus (SLCMV) cause Cassava Mosaic Disease (CMD) in India (Saunders et al., 2002; Hong et al., 1993; Patil et al., 2005). Later, in a biodiversity study, while ICMV was found restricted to only certain regions, SLCMV was found to be rather widespread in southern India. In addition, based on PCR-RFLP from multiple samples, it was concluded that these isolates showed high diversity (Patil et al., 2005; Rothenstein et al., 2006). Phylogenetic analysis of several CMD-affected cassava samples revealed recombination among the population of cassava infecting begomoviruses in India (Rothenstein et al., 2006). Virus free cassava, generated by meristem tip culture, was used to study the whitefly transmissibility of the viruses in cassava. Using cassava adapted whiteflies; symptoms appeared in 85 per cent of the plants after $25^{\text {th }}$ day of inoculation (Duraisamy et al., 2012).

\section{Chilli}

In India, chilli has been reported to be infected by several begomoviruses namely Chilli leaf curl virus (ChiLCV), Tomato leaf curl New Delhi virus (ToLCNDV) and Tomato leaf curl Jodhpur virus (Khan et al., 2006; Senanayake et al., 2007). The presence of a begomovirus was confirmed by PCR while the BLAST search of GenBank revealed close similarity of the sequence with the Chilli leaf curl virus-(Pakistan:Multan) (ChiLCuV-[Pk:Mul]; AF336806) (Shih et al., 2003). In India, Tomato leaf curl New Delhi virus (ToLCNDV) was shown to be associated with chilli leaf curl disease occurring in Lucknow with a diverse group of beta satellites found in crops and weeds (Khan et al., 2006; Kumar et al., 2015).

\section{Cotton}

The first outbreak of CLCuD in the Indian subcontinent, the 'Multan epidemic' occurred in Multan, Punjab province of Pakistan during the 1990s. Production of cotton is severely constrained by cotton leaf curl disease $(\mathrm{CLCuD})$, which is considered as the most complex and economically important disease of cotton (Zubair et al., 2017; Naveen et al., 2017; Sattar et al., 2017).The etiological viral agents associated with this disease are collectively known as CLCuD associated begomoviruses (CABs) belongs to the genus Begomovirus (Sattar et al., 2017; Zerbini et al., 2017; Brown et al., 2015). The genome of the CABs predominantly consists of a monopartite circular ssDNA (Sattar et al., 2017; Brown et al., 2015) frequently associated with non-viral, single stranded circular satellite DNA molecules together presenting as an infection complex (Sattar et al., 2013,2017; Briddon et al., 2006).

Monopartite begomoviruses associated with a beta satellite (Kirthi et al., 2002). At least four begomoviruses are associated with this disease in India, namely, Cotton leaf curl Rajasthan virus (CLCuRV), Cotton leaf curl Multan virus (CLCuMuV), Cotton leaf curl Kokhran virus (CLCuKV) and Tomato leaf curl Bangalore virus (Ahuja et al., 2007). The $\mathrm{CP}$ gene sequence of another Indian isolate, Cotton leaf curl virus-Hissar 2, was reported from Haryana, India, which showed 97.3 per cent amino acid sequence identity with Pakistan cotton leaf curl virus (Sharma et al., 2005). A recent work has identified two new isolates, $\mathrm{CLCuV-SG01} \mathrm{and} \mathrm{CLCuVSG02}$ from Rajasthan, which are reportedly recombinants with other begomoviruses (Kumar et al., 2010). A recombinant CP of a cotton leaf curl virus strain was observed to have non-specific ssDNA binding activity, which demonstrates a possible role of the protein in virus assembly and nuclear transport; this property being possibly conferred by a conserved C2H2-type zinc finger motif (Priyadarshini and Savithri, 2009). 


\section{Cucurbits}

Natural infection of begomoviruses on cucurbitaceous crops have also been reported from India (Muniyappa et al., 2003; Varma and Malathi, 2003; Sohrab et al., 2003,2006; Mandal et al., 2004; Singh, 2005; Tiwari et al., 2011) which revealed that begomoviruses are emerging as a major constraint to cultivation of cucurbitaceous crops in India. Author reported more than 98 per cent samples were found to be infected with Begomovirus (Nagendran et al., 2017). Chlorotic curly stunt disease of bottle gourd from Delhi and adjoining state of Haryana was reported to caused by a begomovirus on the basis of whitefly transmission and sequence identity of coat protein (CP) and replication initiator protein(Rep) genes (Sohrab et al., 2010).

\section{Legumes}

Yellow mosaic disease (YMD) in legumes such as blackgram (Vigna mungo) and mungbean ( $V$. radiata) was first reported by Nariani. It is a major constraint in the productivity of legumes across the Indian subcontinent (Varma and Malathi, 2003). This disease affects the majority of legume crops viz. mungbean, blackgram, pigeonpea, soybean, mothbean and common bean, while causes huge loss of blackgram, mungbean and soybean together (Varma and Malathi, 2003).

Four species of begomoviruses have been reported to cause YMD of legumes in India (Qazi et al., 2007). Mungbean yellow mosaic India virus (MYMIV) and Mungbean yellow mosaic virus (MYMV) are prevalent and the Dolichos yellow mosaic virus and Horsegram yellow mosaic virus, occur rarely (Fauquet and Stanley, 2003; Maruthi et al., 2006). A bipartite begomovirus isolate causing YMD in blackgram produced differential symptom in different leguminous hosts and had DNA-A, a variant of MYMV, and DNA-B, a variant of MYMIV (Haq et al., 2011).

Begomoviral DNA replication is interesting and therefore to understand the properties of Rep and its interacting partners have been the focus of several studies. The Rep of blackgram infecting MYMIV-Bg was found to bind to the intergenic region in a specific manner. The protein also undergoes ATPregulated cleavage and conformational change (Pant et al., 2001). The Rep of MYMIV also acts as a replicative helicase in viral replication and works as a large oligomer, needs less than six nucleotides to function and translocates in $3^{\prime}-5^{\prime}$ direction (Choudhury et al., 2006). Another host factor, RAD54 (a known recombination/repair protein) has also been identified to be an essential interacting partner of Rep of MYMIV. The interacting domain of RAD54 was identified which enhances the enzymatic activities of MYMIV-Rep (Kaliappan et al., 2012).

Transgenes (CP, Rep, Rep-antisense, truncated Rep, NSP and MP) were evaluated by agroinoculation in transgenic tobacco $(N$. tabacum) to attain resistance against mungbean infecting begomoviruses. Transgenic plant harbouring the the antisenseRep ORF showed inhibition of viral DNA accumulation (Shivaprasad et al., 2006).

\section{Papaya}

The CP, Rep and the IR of the genome of a begomovirus causing severe leaf curl in papaya plants were amplified, cloned and sequenced. The viral isolate was found to share 89.9 per cent homology with ICMV and was named as Papaya leaf curl virus-India (PLCV-India). Analyses of the N-terminal 70 amino acid of the CP of the virus showed its relatedness to begomoviruses from the Old World (Saxena et al., 1998). Small fragments 
(siRNAs) were designed using computational tools, could possibly be used to confer resistance against begomovirus infecting papaya (Saxena et al., 2011).

\section{Potato}

A begomovirus causing a severe disease of potato was observed in India (Usharani et al., 2004). The nucleotide sequence data indicate that the cause is a virus closely related to Tomato leaf curl New Delhi virus (ToLCNDV) (Gawande et al., 2007).

\section{Tomato}

Tomato leaf curl disease (ToLCD) is a common disease of tomato all over India. ToLCD was first reported in northern India by Vasudeva and Sam Raj. Symptoms of ToLCD include leaf curling, vein clearing and stunting, which can often lead to sterility. Tomato leaf curl is becoming a serious concern due to involvement of six different species of begomovirus, viz., Tomato leaf curl Bangalore virus (ToLCBV), Tomato leaf curl Bangladesh virus (ToLCBDV), Tomato leaf curl Gujarat virus (ToLCGV) Tomato leaf curl Karnataka virus (ToLCKV), Tomato leaf curl NewDelhi virus (ToLCNDV), and Tomato leaf curl Sri Lanka virus (ToLCVSLV) (Fauquet et al., 2003). In general, the population of Tomato leaf curl viruses (ToLCVs) in India is highly diverse, which was shown after analysis of the $\mathrm{CP}$ sequence from 29 infected tomato samples across India. Five clusters (with less than $88 \%$ similarity among them) were observed among the population; while four of them represented the known tomato leaf curl viruses, one cluster showed more similarity (89\%) with Croton yellow vein mosaic virus (Reddy et al., 2005).

Potential recombination sites among the DNA-A components of the strains/species of
ToLCVs from Bangalore were mapped in an early study (Kirthi et al., 2002). There has been report of a distinct bipartite begomovirus from a temperate region (Palampur), which is possibly a natural pseudo recombinant (Kumar et al., 2008). Possible recombination has also been reported in two monopartite begomoviruses, one from New Delhi (ToLCV-CTM) and another from Kerala ToLCV-K3/K5 (Pandey et al., 2010). It was demonstrated that changes in DNA-A virionsense mRNA structure or translation affect viral replication (Padidam et al., 1996).

There have been several efforts to confer resistance against the tomato leaf curl viruses in India using different strategies. Transgenic tomato lines harbouring the $\mathrm{CP}$ of ToLCNDV-[India: Lucknow] were generated, which showed durable resistance against the virus (Raj et al., 2005). Transgenics carrying antisense sequence of Rep gene was shown to recover from ToLCD (Praveen et al., 2005a, b). In a biosafety analysis, the above transgenics were shown to be non-toxic to mice (Singh et al., 2009), thereby making the product easily acceptable to consumers. Virus-induced gene silencing (VIGS) vector are useful tools for the study of gene functions in plants. It was also shown that a mutation in the AC3 (a putative silencing suppressor) can increase the silencing efficiency several folds (Pandey et al., 2009). Genetic resistance against geminiviruses is known in some crops which can act as sources of resistance, and as subjects for study of plant-pathogen interaction. ToLCNDV-resistant cultivar H-88-78-1 has been found to differentially express 106 transcripts in response to viral infection, eight of which were induced more than fourfold compared to an un-infected control. They represented proteins participating in defence response, transcription, proteolysis and hormone signalling (Sahu et al., 2010). Such studies will help in the deployment of genes 
in developing virus resistance using transgenics and marker assisted selection.

India is an agriculture based country therefore a large number of begomoviruses have been reported from the country. Indian weather is very much suitable for the prevalence and survival of white fly. Indian begomovirus have an overlapping host range for example tomato-infecting begomoviruses have also been reported in chilli, cotton and mentha. One of the major factors responsible for this overlapping host range could be the polyphagous nature of the vector whitefly and the mixed cropping system prevalent in the country. An expected consequence of this scenario would be recombination which could play an important role for the evolution of new begomovirus strains in India and these new strains could be responsible for severe losses in new host varieties. The emergence of a large number of beta satellites and more recently, alpha satellites associated with begomoviruses in India is also remarkable. The interdependence of the satellites and their helper begomoviruses is thus an area of immense importance for investigation. Thus, there is an urgent need to control begomovirus infections in new host varieties. The use of computational and molecular techniques e.g. RNAi could be a potential tools for reducing the prevalence of various begomovirus diseases. The reports of success in controlling begomoviruses with virus derived and other transgenes are encouraging. Well characterized resistance genes hold a lot of promise in controlling begomoviruses. However, as mentioned earlier, only a few such genes have been characterized to a level where they can be used for breeding to develop resistance against begomovirus and can be used to intrigues into popular crop varieties. Hence, more research works to be undertaken to search for natural begomovirus resistant wild varieties of crop plants against begomoviruses and when found, to characterize the resistance traits. The interaction of begomoviruses with the vector whiteflies, a crucial step in the spread of begomoviruses in the field, also needs to be carefully looked at. These, as well as the exciting developments on plant-virus interactions, promise many more avenues of begomovirus control opening up in the near future. These need to be urgently deployed to assure crop protection against the huge losses incurred due to begomoviral infections in India. Results of these techniques should be effectively applied for disease management, crop protection and development of quarantine strategies at state and national level in India.

\section{References}

Ahuja, S.L., Monga, D., and Dhyal, L.S. 2007. Genetics of Resistance to Cotton Leaf Curl disease in Gossypium hirsutum L. under Field Conditions. J. Hered. 98, 79-83.

Borah, B.K. and Dasgupta, I. 2012. Begomovirus research in India: A critical appraisal and the way ahead. J. Biosci. 37, 791-806.

Briddon, R.W., and Stanley, J. 2006. Subviral agents associated with plant single stranded DNA viruses. Virology. 344, 198-210.

Brown, J.K., Fauquet, C.M., Briddon, R.W., Zerbini, M., Moriones, E., Castillo, JN. 2012. Geminiviridae. In: King AMQ, Adams, M.J., Carstens, E.B., Lefkowitz, EJ. eds. Virus Taxonomy: Ninth Report of the International Committee on Taxonomy of Viruses. London, UK: Associated Press, 351-73.

Brown, JK., Zerbini, FM., Castillo, NJ., Moriones, E., Sobrinho, RR., Silva, JC., Olive, FE., Briddon, RW., Zepeda, HC., Idris, A., Malathi, VG., Martin, DP., Bustamante, RR., Ueda, S., and Varsani, A. 2015. Revision of Begomovirus 
taxonomy based on pairwise sequence comparisons. Arch. Virol. 160, 15931619.

Castillo, JN., Olivé, E.F., and Campos, SS. 2011. Emerging virus diseases transmitted by whiteflies. Annu. Rev. Phytopathol. 49, 219-248.

Choudhury, N.C., Malik, PS., Singh, D.K., Islam, M.N., Kaliappan, K., and Mukherjee, S.K. 2006. The oligomeric Rep protein of Mungbean yellow mosaic India virus (MYMIV) is a likely replicative helicase. Nucleic Acids Res. 34, 6362-6377.

Czosnek, H. 2007. Tomato yellow leaf curl virus disease: management, molecular biology, breeding for resistance; Springer: Dordrecht, The Netherlands., pp.1-420.

Dasgupta, I., Malathi, V.G., and Mukherjee, S.K. 2003. Genetic engineering for virus resistance. Curr. Sci. 84, 341-354.

Duraisamy, R., Natesan, S., Muthurajan, R., Gandhi, K., Lakshmanan, P., Karuppasamy, N., and Chokkappan, M. 2012. Molecular studies on the transmission of Indian cassava mosaic virus (ICMV) and Sri Lankan cassava mosaic virus (SLCMV) in cassava by Bemisia tabaci and cloning ICMV and SLCMV replicase gene from cassava. Mol. Biotechnol. DOI: 10.1007/s12033012-9503-1.

Fauquet, C.M., and Stanley, J. 2003. Geminivirus classification and nomenclature; progress and problems. Ann. Appl. Biol.142:165-189.

Fauquet, C.M., Bisaro, D.M., Briddon, R.W., Brown, J., Harrison, B.D., Rybicki, E.P., Stenger, D.C., and Stanley, J.2003. Revision of taxonomic criteria for species demarcation in the Geminiviridae family, and an updated list of begomoviral species. Arch. Virol. 148: 405-421.
Fauquet, C.M., Briddon, R.W., Brown, J.K., Moriones, E., Stanley, J., Zerbini, M., and Zhou, X. 2008. Geminivirus strain demarcation and nomenclature. Archives of Virology. 153, 783-821.

Gawande, S.J., Kaundal, P., Kaushal, N., and Garg, I.D. 2007. Print capture PCR-A simple technique for the detection of tomato leaf curl New Delhi virus causal agent of potato apical leaf curls disease in India. Potato J. 34, 87-88.

Gopal, P., Kumar, P.P., Sinilal, B., Jose, J., Yadunandam, A.K., and Usha, R. 2007. Differential roles of $\mathrm{C} 4$ and $\beta-\mathrm{C} 1$ in mediating suppression of posttranscriptional gene silencing: Evidence for transactivation by the $\mathrm{C} 2$ of Bhendi yellow vein mosaic virus, a monopartite begomovirus. Virus Res.123, 9-18.

Haq, Q.M.I., Rouhibakhsh, A., Ali, A., and Malathi, V.G. 2011. Infectivity analysis of a blackgram isolate of Mungbean yellow mosaic virus and genetic assortment with MYMIV in selective hosts. Virus Genes. 42, 429-439.

Harrison, B.D., Swanson, M.M., and Fargette, D. 2002. Begomovirus coat protein: serology, variation and function. Physiol. Mol. Plant Pathol. 60, 257-271.

Hong, Y.G., Robinson, D.J., and Harrison, B.D. 1993. Nucleotide sequence evidence for the occurrence of three distinct whitefly transmitted Gemini viruses in cassava. J. Gen. Virol. 74, 2437-2443.

Idris, A.M., Shahid, M.S., Briddon, R.W., Khan, A.Z.J., and Brown, J.K. 2011. An unusual alpha satellite associated with monopartite begomoviruses attenuates symptoms and reduces beta satellite accumulation. J. Gen. Virol. 92, 706717.

Jose, J., and Usha, R. 2003. Bhendi yellow vein mosaic disease in India caused by association of a DNA $\beta$ satellite with a begomovirus. Virology. 305, 310-317. 
Kaliappan, K., Choudhury, N.R., Suyal, G., and Mukherjee, S.K. 2012. A novel role for RAD54: this host protein modulates geminiviral DNA replication. FASEB J. 26, 1142-1160.

Khan, MS., Raj, SK., and Singh, R. 2006. First report of Tomato leaf curl New Delhi virus infecting chilli in India. Plant Pathol. 55, 289.

Kirthi, N., Maiya, S.P., Murthy, M.R.N., and Savithri, H.S. 2002. Evidence for recombination among the tomato leaf curl virus strains/species from Bangalore, India. Arch. Virol. 147, 255272.

Kumar, A., Kumar, J., and Khan, A. 2010. Sequence characterization of cotton leaf curl virus from Rajasthan: phylogenetic relationship with other members of geminiviruses and detection of recombination. Virus Genes. 40, 282 289.

Kumar, P.P., Usha, R., Zrachya, A., Levy, Y., Spanov, H., and Gafni, Y. 2006. Protein-protein interactions and nuclear trafficking of coat protein and $\beta \mathrm{C} 1$ protein associated with Bhendi yellow vein mosaic disease. Virus Res. 122, 127-136.

Kumar, R.V., Singh, A.K., Singh, A.K., Yadav, T., Basu, S., Kushwaha, N., Chattopadhyay, B., and Chakraborty, S. 2015. Complexity of begomovirus and beta satellite populations associated with chilli leaf curl disease in India. J. Gen. Virol. 96, 3143-3158.

Kumar, Y., Hallan, V., and Zaidi, A.A. 2008. Molecular characterization of a distinct bipartite begomovirus species infecting tomato in India. Virus Genes. 37, 425431.

Mandal, B., Mandal, S., Sohrab, S.S., Pun, K.B., and Varma, A. 2004. A new yellow mosaic disease of chayote in India. Plant Pathol. 53:797.
Maruthi, M.N., Manjunatha, B., Rekha, A.R., Govindappa, M.R., Colvin, J., and Muniyappa, V. 2006. Dolichos yellow mosaic virus belongs to a distinct lineage of Old World begomoviruses; its biological and molecular properties. Ann. App. Biol. 149:187-195.

Muniyappa, V., Maruthi, M.N., Babitha, C.R., Colvin, J., Briddon, R.W., and Rangaswamy, K.T. 2003. Characterization of Pumpkin yellow vein mosaic virus from India. Ann. App. Biol. 142:323-331.

Nagendran, K., Kumar, SM., Aravintharaj, R., Balaji, C.G., Manoranjitham, S.K., Singh, A.K., Rai, A.B., Singh, B., and Karthikeyan, G. 2017. The occurrence and distribution of major viruses infecting cucurbits in Tamil Nadu state, India. Crop Protec. 99:10-16.

Naveen, N.C., Haubey, R.C., Kumar, D., Rebijith, K.B., Rajagopal, R., Subrahmanyam, B., and Subramanian, S. 2017. Insecticide resistance status in the whitefly, Bemisia tabaci genetic groups Asia-I, Asia-II-1 and Asia-II-7 on the Indian subcontinent. Sci. Rep. 7, 40634.

Padidam, M., Beachy, R.N., and Fauquet, C.M. 1996. The Role of AV2 ("precoat") and coat protein in viral replication and movement in Tomato leaf curl geminivirus. Virology. Pp. 390-404.

Pandey, P., Choudhury, N.R., and Mukherjee, S.K. 2009. A geminiviral amplicon (VA) derived from Tomato leaf curl virus (ToLCV) can replicate in a wide variety of plant species and also acts as a VIGS vector. Virol. J. 6, 152-164.

Pandey, P., Mukhopadhyay, S., Naqvi, A.R., Mukherjee, S.K., Shekhawat, G.S., and Choudhury, N.R. 2010. Molecular characterization of two distinct monopartite begomoviruses infecting tomato in India. Virol. J. 7, 337. 
Pant, V., Gupta, D., Choudhury, N.R., Malathi, V.G., Varma, A., and Mukherjee, SK. 2001. Molecular characterization of the Rep protein of the blackgram isolate of Indian mungbean yellow mosaic virus. J. Gen. Virol. 82, 2559-2567.

Patil, B.L., Rajasubramaniam, S., Bagchi, C., and Dasgupta, I. 2005. Both Indian cassava mosaic virus and Sri Lankan cassava mosaic virus are found in India and exhibit high variability as assessed by PCR-RFLP. Arch. Virol. 150, 389397.

Pratap, D., Kashikar A.R., and Mukherjee S.K., 2011. Molecular characterization and infectivity of a Tomato leaf curl New Delhi virus variant associated with newly emerging yellow mosaic disease of eggplant in India. Virol. J. DOI: 10.1186/1743-422X-8-305.

Praveen, S., Kushwaha, C.M., Mishra, A.K., Singh, V., Jain, R.K., and Varma, A. 2005a. Engineering tomato for resistance to tomato leaf curl disease using viral rep gene sequences. Plant Cell Tiss. Org. Cult. 83, 311-318.

Praveen, S., Mishra, A.K., and Dasgupta, A. 2005b. Antisense suppression of replicase gene expression recovers tomato plants from leaf curl infection. Plant Sci. 168, 1011-1014.

Priyadarshini, C.G.P., and Savithri, H.S. 2009. Kinetics of interaction of Cotton leaf curl Kokhran virus-Dabawali (CLCuKV-Dab) coat protein and its mutants with ssDNA. Virology. 386, 427-437.

Pun, K.B., and Doraiswamy, S. 1999. Effect of age of okra plants on susceptibility to Okra yellow vein mosaic virus. Indian J. Virol.15, 57-58.

Qazi, J., Ilyas, M., Mansoor, S., and Briddon, B. 2007. Legume yellow mosaic viruses: genetically isolated begomoviruses. Mol. Pl.Path. 8:343348.

Raj, S.K., Singh, R., Pandey, S.K., and Singh, B.P. 2005. Agrobacterium mediated tomato transformation and regeneration of transgenic lines expressing Tomato leaf curl virus coat protein gene for resistance against TLCV infection. Curr. Sci. 88, 1674-1679.

Reddy, R.V.C., Colvin, V., Muniyappa, V., and Seal, M. 2005. Diversity and distribution of begomoviruses infecting tomato in India. Arch. Virol. 150, 845867.

Rothenstein, D., Haible, D., Dasgupta, I., Dutt, N., Patil, B.L., and Jeske, H. 2006. Biodiversity and recombination of cassava-infecting begomoviruses from southern India. Arch. Virol. 151, 55-69.

Sahu, P.P., Rai, N.K., Chakraborty, S., Singh, M., Chandrappa, P.H., Ramesh, B., Chattopadhyay, D., and Prasad, M. 2010. Tomato cultivar tolerant to Tomato leaf curl New Delhi virus infection induces virus-specific short interfering RNA accumulation and defence-associated host gene expression. Mol. Plant Pathol. 11, 531544.

Sattar, M.N., Iqbal, Z., Tahir, M.N., and Ullah, S. 2017. The Prediction of a New Cotton Leaf Curl Disease Epidemic in the Old World. Front. Microbiol. 8, 631, https://doi.org/10.3389/fmicb.2017.006 31.

Sattar, M.N., Kvarnheden, A., Saeed, M., and Briddon, R.W. 2013. Cotton leaf curl disease-an emerging threat to cotton production worldwide. J. Gen. Virol. 94, 695-710.

Saunders, K., Nazeera, S., Mali, V.R., Malathi, V.G., Briddon, R.W., Markham, P.G., and Stanley, J. 2002. Characterisation of Sri Lankan cassava mosaic virus and Indian cassava mosaic virus: Evidence for acquisition of a 
DNA B component by a monopartite begomovirus. Virology. 293, 63-74.

Saxena, S., Hallan, V., Singh, B.P., and Sane, P.V. 1998. Nucleotide sequence and intergeminiviral homologies of the DNA-A of papaya leaf curl geminivirus from India. Biochem. Mol. Biol. Intl. 45, 101-113.

Saxena, S., Singh, N., Ranade, S.A., and Babu, S.G. 2011. Strategy for a generic resistance to geminiviruses infecting tomato and papaya through in silico siRNA search. Virus Genes. 43, 409434.

Senanayake, D.M.J.B., Mandal, B., Lodha, S., and Varma, A. 2007. First report of Chilli leaf curl virus affecting chilli in India. Plant Pathology. 56, 343.

Sharma, M., Thakur, P.D., Gupta, D., and Thakur, A.K. 2012. Sources of resistance in squash germplasm against viral diseases. Plant Dis. Res. 27(2):239-241.

Sharma, M., Thakur, P.D., Gupta, D., and Thakur, A.K. 2013. Identification of viruses and screening of summer squash (Cucurbita pepo) germplasm against viral diseases under controlled conditions. Indian J. Agri. Sci. 83(4):426-30.

Sharma, P., Rishi, N., and Malathi, V.G. 2005. Molecular cloning of Coat protein gene of an Indian Cotton leaf curl virus (CLCuVHS2) isolate and its phylogenetic relationship with others members of Geminiviridae. Virus Genes. 30, 85-91.

Shih, SL., Tsai, W.S., Green, S.K. 2003. Molecular characterization of tomato and chilli leaf curl begomoviruses from Pakistan. Plant Dis. 87, 200.

Shivaprasad, P.V., Thomas, M., Balamani, V., Biswas, D., Vanitharani, R., Karthikeyan, A.S., and Veluthambi, K. 2006. Factors contributing to deletion within Mungbean yellow mosaic virus partial dimers in binary vectors used for agroinoculation. J. Virol. Methods. 137, $72-81$

Singh, A.K., Praveen, S., Singh, B.P., Varma, A., and Arora, N. 2009. Safety assessment of leaf curl virus resistant tomato developed using viral derived sequences. Transgenic Res. 18, 877887.

Singh, R., 2005. Molecular characterization of a virus causing yellow mosaic disease in Cucurbita maxima and development of diagnostics for the detection of the virus, $\mathrm{Ph} \mathrm{D}$ thesis, Lucknow University, Lucknow.

Sohrab, S.S., Mandal, B., Ali, A., and Varma, A. 2006. Molecular diagnosis of emerging begomovirus diseases in cucurbits occurring in northern India. Indian J Virol. 17:88-95.

Sohrab, S.S., Mandal, B., Ali, A., Varma, A. 2010. Chlorotic Curly Stunt: A Severe Begomovirus Disease of Bottle Gourd in Northern India. Indian J. Virol. 21(1):56-63.

Sohrab, S.S., Mandal, B., Pant, R.P., and Varma, A. 2003. First report of association of Tomato leaf curl New Delhi virus with yellow mosaic disease of Luffa cylindrica in India. Plant Dis. 87:1148.

Tiwari, A.K., Snehi, SK., Singh, R., Raj, S.K., Rao, G.P., and Sharma, P.K. 2011. Molecular identification and genetic diversity among six Begomovirus isolates affecting cultivation of cucurbitaceous crops in Uttar Pradesh, India. Archives of Phytopathology and Plant Protection. DOI: 10.1080/03235400903458803.

Usharani, K.S., Surendranath, B., Khurana, S.M.P., Garg, I.D., and Malathi, V.G. 2004. Potato leaf curl-a new disease of potato in northern India caused by a strain of Tomato leaf curl New Delhi virus. Plant Pathol., 53. 235. 
Vanderschuren, H., Stupak, M., Futterer, J., Gruissem, W., and Zhang, P. 2007. Engineering resistance towards geminiviruses - review and perspectives. Plant Biotech. J. 5, $207-$ 220.

Varma, A., and Malathi, V.G. 2003. Emerging geminivirus problems. A serious threat to crop production. Ann. Appl. Biol., 142:145-164.

Varma, A., Mandal, B., and Singh, M. 2011. Global emergence and spread of whitefly (Bemisia tabaci) transmitted Gemini viruses. In The Whitefly, Bemisia tabaci (Homoptera: Aleyrodidae) Interaction with Geminivirus-Infected Host Plants; Thompson, W.M.O., Ed.; Springer: Dordrecht, The Netherlands. pp. 205292.

Varsani, A., Castillo, J.N., Moriones, E., Zepeda, C.H., Idris, A., Brown, J., Zerbini, F.M., and Martin, D. 2014. Establishment of three new genera in the family Geminiviridae: Becurtovirus, Eragrovirus and Turncurtovirus. Arch. Virol. 159, 2193-2203.

Venkataravanappa, V., Lakshmi narayana, R.C., Swarnalatha, P., Devaraju, A., Jalali, S., and Reddy, MK. 2012b. Molecular evidence for association of Cotton leaf curl Alabad virus with yellow vein mosaic disease of okra in North India. Archives Phytopathol Plant Protec. 45, 1-19.

Venkataravanappa, V., Reddy, C.N.L., Devaraju, A., Jalali, S., and Reddy, MK. 2013b. Association of Cotton leaf curl Bangalore virus with yellow vein mosaic disease of okra is further evidence for natural recombination of begomoviruses in India. Indian J. Virol. 24, 188-98.

Venkataravanappa, V., Reddy, C.N.L., Jalali, S., and Reddy, MK. 2012a. Molecular characterization of distinct bipartite begomo virus infecting bhendi (Abelmoschus esculentus L.) in India. Virus Genes. 44, 522-35.

Venkataravanappa, V., Reddy, C.N.L., Jalali, S., Reddy, MK. 2013a. Molecular characterization of a new species of begomovirus associated with yellow vein mosaic of bhendi (Okra) in Bhubhaneswar, India. European J. Plant Pathol. 136, 811-22.

Voinnet, O., 2005. Induction and suppression of RNA silencing: Insights from viral infections. Nat. Rev. Genet. 6, 206-221.

Zaidi S.S., Shakir S., Farooq, M., Amin, I., Scheffler, J.A., Scheffler B.E., and Mansoor S. 2017. Multiple begomoviruses found associated with cotton leaf curl disease in Pakistan in early 1990 are back in cultivated cotton. Sci. Rep. 7, 680, https://doi.org/ 10.1038/s41598-017-00727-2.

Zerbini, F.M., Briddon, RW., Idris, A., Martin, D.P., Moriones, E., Castillo, J.N., Bustamante, RR., Roumagnac, P., and Varsani A. 2017. ICTV Virus Taxonomy Profile: Geminiviridae. J. Gen. Virol. 98, 131-133.

\section{How to cite this article:}

Manju Sharma, Priya Singh, A.K. Tewari and Pranesh Lavania. 2018. The Current Status of Begomovirus Research in India: Solemn Threat to Crop Production. Int.J.Curr.Microbiol.App.Sci. 7(09): 288-299. doi: https://doi.org/10.20546/ijcmas.2018.709.036 